\title{
Homer's Odysseus as an Ecstatic Voyager
}

\author{
F. Gordon Greene \\ Sacramento, $C A$
}

ABSTRACT: There are profound experiential and symbolic parallels linking the imagery of Homer's Odyssey and the psychophysical characteristics of ecstatic out-of-body and near-death experiences. I examine this epic's events chronologically, identifying and analyzing specific instances where Homer's imagery suggests such a multifaceted relationship. In accounting for this relationship, I introduce a psychospiritual evolutionary theory of symbolism and inspiration based upon the higher dimensional existence of the supernatural. In such a reading, Homer's Odyssey serves, in part, as an eschatological text sharing much in common with "books of the dead" from a variety of human cultures.

As the first attempt in Western literature to grapple with the ultimate mystery of death, Homer's Odyssey (1967) will always be revered as a classic. The Greek hero Odysseus sailed by ship to the ends of the Earth. On his way, he traveled to many exotic lands where he encountered a variety of grotesque monsters, supernatural beings and minor divinities. Once arrived, he visited Hades, the land of the dead, to converse with phantoms of the dead and other supernatural beings of the underworld. Eventually, after many additional hardships and supernatural confrontations, Odysseus found his way back home safely to the Greek island of Ithaka.

Homer's Odyssey is, I believe, more than just a hopelessly naive attempt by a primitive people to penetrate the mystery of death. On the contrary, this epic voyage, I argue, contains numerous profound examples of imagery related experientially and symbolically to an

F. Gordon Greene is a free-lance writer whose principal interests have been parapsychology, religion, and metaphysics. Reprint requests should be addressed to Mr. Greene at P.O. Box 163683, Sacramento, CA 95816. 
actual passage by human consciousness out of the world of nature into the realm of the supernatural and back again. This particular interpretation has been inspired by my own understanding of recent findings concerning the implications of out-of-body experiences (OBEs) and near-death experiences during which experiencers seem to engage in ecstatic otherworld journeys.

Common sensations during such voyages include feelings of floating out of the physical body and of passing through long, dark tunnels, empty voids, or fluidic spaces to emerge, for brief periods, into worlds of paradisiacal splendor. In OBE-related ecstasy, the journey may begin during dreams, borderline sleep states, meditation, contemplative prayer, waking fantasy, or after the ingestion of psychedelic substances. In NDE-related ecstasy, the journey may begin after the experiencer's body has been propelled into life-threatening unconsciousness or even, paradoxically, after a perceived threat to life that is unexpectedly avoided.

While I draw upon recent evidence to make my argument, there is nothing new in the idea that Homer's Odyssey involves an otherworld journey. Speaking of this epic voyage in his literary and historical study of ecstatic otherworld journeys, Ioan Couliano (1990) noted that "All of these territories [visited by Odysseus] are not strictly this worldly, and Odysseus's voyage can be-and has beeninterpreted as simply symbolic" (pp. 114-115). Couliano meant, of course, symbolic of an ecstatic otherworld journey.

By contemplating the imagery of Homer's Odyssey in light of recent understandings of ecstatic journeys, I believe that we may be able to illuminate further the words of this ancient Greek bard as well as learn something more about such journeys. The parallels I shall identify in this exercise suggest that Homer's Odyssey may be looked upon, in one sense, as a guidebook to death-transitional and afterlife-visionary states of consciousness. In such a reading, Homer's epic poem of voyage into the supernatural performs a role similar to that of such eschatological texts as the Egyptian Book of the Dead, the Tibetan Bardo Thodol, and the Ars Moriendi literature of medieval Europe.

\section{Mycenaean Age Cosmology}

We will begin our quest by reviewing briefly cosmological and mythological beliefs from the age of which Homer spoke: the Myce- 
naean age, circa $1400 \mathrm{BC}$. These beliefs, it should be noted, are filtered down to us through the subsequent Greek dark age (circa 1200$900 \mathrm{BC}$ ) as well as through the slowly emerging classical period that reached its cultural zenith between 600 and $400 \mathrm{BC}$.

In this distant age, the Earth was conceived to be a flat, sky domed disk of enormous breadth. A central land mass was conceived to be surrounded by an immense outer sea called the river of Okeanos. This land mass, in turn, surrounded an inner sea, the Mediterranean. Circumscribing not only on all sides but also extending above and below this natural region was a supernatural or divine region, the home of the Olympian gods. The sky above was ruled by Zeus, chief god of the Olympian pantheon. Circling around this land mass in the "endless salt water" (Homer, Book V, line 100) was Zeus's brother, Poseidon, lord of all the sea. And underneath this disk in the bowels of the Earth ruled Zeus's brother Hades, lord of the underworld.

From their varying locations outside the natural realm, the gods would influence human affairs through the use of thunder, lightning, earthquakes, and other displays of divine power. More intimately, the gods might communicate their wishes through the intermediary of human dreams, trance states, or other humanly experienced visionary states of consiousness. In pre-Mycenaean times, it was believed, the gods came face to face with human beings. By the time of the Mycenaean age, however, only in veiled form would a god or goddess venture directly into the human condition, disguised, for example, as an animal or an ordinary mortal. The closer a human being traveled to the edge of the natural universe, the greater his or her chance became of coming into "unveiled" contact with one of the gods or with some other supernatural being.

Looking down into this world from the vantage point of our "superior" cosmic perspective, much as Olympian gods might gaze down into this land of "mere mortals," let us now follow the sequence of events chronologically as they occurred in Homer's mythic time stream, stopping appropriately along the way to examine the parallels in question.

\section{The Voyage of Odysseus and Out-of-Body Experience}

Homeward bound in their fleet of "hollow ships" after victory against Troy, Odysseus, king of Ithaka, and his fellow Greek warriors 
were blown off course and forced westward into unknown waters. The farther west and off course they strayed, the farther Odysseus and his companions wandered from the natural world and the closer they came to the supernatural. Many of the adventures they underwent and the conflicts they endured would seem to take place in an intermediate region situated somewhere between the realms of nature and supernature.

In terms of a clearly recognizable link, the initial OBE phase of the ecstatic journey does not appear to correlate well with the imagery in the Odyssey. This is because there is no imagery present at the outset of this epic that clearly correlates with the principal experiential characteristics of out-of-body awareness: the primarily visual sensation that one is looking back at one's physical body as if from an exterior position in space. This lack of a clearcut visual sensation correlate presents us, I believe, with the weakest link in my argument. Yet additional contemplation of this problem opens up the following significant, if secondary, correlations. The launching of the hollow ships from the solid land of the known world to voyage out into the waters of the mysterious sea may be seen to represent symbolically the OBE, when the OBE is conceived of as the initial phase in the ecstatic journey.

The classical scholar Carl Ruck (1978) observed that "Examples abound in Greek mythology associating the water journey with transport to another world" (p. 99). Sensations of floating, we should note, are not only characteristic of movement through water. The predominant kinesthetic characteristic of the OBE is the sensation of floating freely through the air. Not infrequently the "air," sensed from the out-of-body perspective, is said to possess fluidic properties. And the out-of-body form is sometimes described as ideoplastic while possessing characteristics of permeability ordinarily associated with fluids. When we extend this question of water passage from the initial OBE period to the subsequent penetration into other realms, the following words of Michael Whiteman (1978) take on a particular significance:

In transitional states between a physical state and a psychical one, or between a psychical state and a mystical one, instead of one space gradually or suddenly displacing the other, there is sometimes a kind of dissolution of the "world" into a condition of shapeless fluidity when all we are conscious of is a substantial movement of currents eddying and interweaving in space. Then, in due course, the new "world" and our new personal form are condensed out of "the waters." (pp. 291-292) 
Passage through treacherously narrow waterways against strong currents as well as passage through whirlpools and caves form essential portions of the imagery in the Odyssey. Similarly, passages through eddies and tides and through twirling spaces and long, dark enclosures are commonly reported elements of the ecstatic journey (Gallup and Proctor, 1982). Robert Crookall (1972) commented upon the fluidic sensations sometimes associated with ecstatic journeys. These sensations have been likened by ecstatic voyagers to "a shining river," "a well of water," "a fringe, which had to be crossed-with sinister fluids," "shadow forms," and "something that is misty" (Crookall, 1972, pp. 50-51).

As this argument pertains to the NDE-related ecstasy, we make note of the following possible initiatory parallels. Serious accidents, falls from great heights, and incidents of near-drowning (Audette, 1982; DeQuincy, 1862/1956) have all served as catalysts for NDEs. Odysseus and his companions were continually confronted by potentially life-threatening dangers, not the least of which was the danger of drowning. Thus we see depicted in this epic any one of a number of different initiatory triggers commonly associated with NDEs.

\section{Land of the Lotus-Eaters}

The first island Odysseus and his companions visited was the land of the Lotus-Eaters. Odysseus sent a shore party into the interiors of this realm to gather the supplies needed to continue their voyage. They joined the natives of this land in consuming the fruit of the lotus. Whosoever ate the lotus fruit lost all ambition other than the desire to consume this fruit perpetually. When this party had not returned, Odysseus sent out another landing party to discover what had happened to the first. They too partook of the lotus and succumbed to its irresistible attraction. When he personally went out to discover what had happened he learned of the danger confronting his expedition. Odysseus instructed those in his command who had not eaten the lotus not to consume this fruit and ordered them to escort those Greeks who had back, by force, to their ships. Odysseus and his men immediately set sail to escape the dangerous attraction of this strange land.

In her book The Hero and the Goddess, Jean Houston (1992) speculated that the voyage to the land of the Lotus-Eaters involved 
the passing from the world of waking consciousness to the world of dreams, from the world of rational expression to one of metaphorical speech, and finally from the bound, structured world of the local self to the more fluid and surprising levels of the mythic and archetypal domain. (p. 102)

Another possible mode of understanding this land is found in an interpretation of the chronicles of the well-known ecstatic voyager Robert Monroe. In his book Far Journeys, Monroe (1985) described a visit to a Dantesque-like realm to which he was drawn by a powerful sexual current. He recognized what he believed to be the souls of apparently deceased human beings of both genders manifesting in the forms of naked human bodies. They were heaped atop one another forming an immense pile of wriggling, copulating flesh. After several unsuccessful attempts to communicate with one participant in this cosmic orgy, Monroe left this scene in a despondent mood. Monroe likened the participants of this cosmic orgy to a can of squiggling worms and speculated that they may have been castoffs of the human race.

Obviously, the correlation I propose, based upon Monroe's account, can be nothing more than suggestive. This interpretation does, however, offer us one example of a possible otherworld realm corresponding in some sense to the land of the habitually rapacious Lotus-Eaters. The consumption of fruit, we should observe, is frequently associated symbolically with the sexual act. As we shall see further on in this paper, the sexual impulse, as it may be seen to pertain to the ecstatic journey and to Homer's Odyssey, possesses not only negative but also positive connotations.

\section{Giants and Witches on the Way to Hades}

Following their escape from the land of the Lotus-Eaters, Odysseus and his men visited the island of Aiolos, mortal king in charge of the winds. They secured from him enough wind, contained in a bag, to enable their sails to ply these mysterious seas uninterruptedly all the way back to the vicinity of their homeland. Yet while Odysseus slept, several of his men became curious to see what else may have been contained in this bag and opened it against his orders. The remaining wind escaped in a flurry, once again blowing the fleet of Odysseus off course into unknown waters. 
Of possible significance here is an observation by Robert Graves (1951). The winds, he noted, were thought of among certain ancient Greeks as souls of the dead. Drawing upon this belief, perhaps it is not too far-fetched to make the following suggestion. The permanent release of these "vital spirits" from Aiolos's bag in a single "expiration" may be seen to symbolize the "death" of Odysseus and his men. In other words, the release of these winds may be seen to foreshadow the eventual trip Odysseus and his men were destined to make to Hades.

Odysseus and his men went on to spot land again and anchored their ships off the coast of an unknown country. This country was, as they were to discover to their dismay, the land of the Cyclopes, a race of primitive one-eyed giants who dressed in animal skins, lived in caves, and tended flocks of sheep. A shore party headed by Odysseus became trapped inside the cave of the Cyclops Polyphemos, son of Poseidon. The enormous boulder Polyphemos placed across the entrance to the cave was far too immense for Odysseus and his men to remove. After a number of Greeks were eaten raw by this barbarous "host," Odysseus devised a ruse that he hoped would enable the remainder to escape. He offered Polyphemos wine taken on this expedition, the better to swallow the tough and stringy Greeks being fasted upon. In drinking this wine, Polyphemos passed out in a drunken stupor. This was the moment for which Odysseus has been waiting. He had secretly fashioned a large stake whose tip was now placed inside the cave's fire until it was red hot. Odysseus plunged the stake into this monster's sole eye bursting the socket with a searing pop.

The blinded Polyphemos awakened in agonizing pain no longer able to grab his human prey. Still, these Greeks were trapped in his cave and there he planned to keep them. Later, the now blinded Polyphemos removed the boulder while carefully positioning himself in its place. He ushered his flock of sheep out to graze on pasture lands, carefully feeling to make sure that no Greeks escaped alongside his flock. He then put the boulder back in place. Despite this precaution, Odysseus and his men eventually escaped beneath the bellies of these sheep.

After escaping, just as he and his men were disembarking from the shore of the Cyclopes' land, Odysseus shouted out his name to Polyphemos, telling the Cyclops that it was he, Odysseus, who wielded the blinding stake. In succumbing to this senseless act of hubris, Odysseus condemned himself and his men to years of additional wanderings through mysterious seas and unknown lands. This was because the blinded Polyphemos implored his father, the sea god 
Poseidon, to exact revenge upon Odysseus and his men for the loss of his sole Cyclopean eye.

Common among preliterate peoples into modern times, we should note, is the belief that a person's name is somehow sympathetically linked to his or her soul (Frazer, 1922). Often a person's "true name" is kept secret to all but that person's closest friends to ensure that a magical curse will not be cast using this "true name" to harm the soul. If we assume that such a belief was prevalent among Mycenaean age Greeks, Odysseus, in shouting out his name, had acted recklessly. He had invited the wrath of the gods down upon himself and his men.

Next Odysseus and his men visited the land of the Laistrygones, another race of cannibalistic giants. These giants hurled huge boulders down upon the Greek ships that had become anchored in the cave-like harbor of this land. Every ship and crew member in the fleet except those of Odysseus were destroyed in this catastrophic pelting. Only Odysseus, having learned from his mistake of being cornered in the cave of Polyphemos, had developed the foresight to anchor his ship outside the harbor, thereby avoiding the fate to which the rest of his fleet succumbed.

Odysseus and his remaining companions voyaged on to the land of the enchantress Circe. Circe offered members of the first Greek landing party who entered into her realm wine and food. While partaking of these offerings, they were caught off guard. Circe was able to transform them all into wolves and swine before they were able to unsheath their swords or string their bows. Yet another landing party was disarmed and transformed, by the same artifice.

As Odysseus was heading inland to discover the fate of his men, he was stopped by Hermes, the divine messenger of the gods, who had been dispatched from Olympos. Hermes warned Odysseus of Circe's witching ways. He gave Odysseus the magical mole root that would neutralize Circe's magic along with the advice that would enable Odysseus to overcome and dominate her. When Odysseus arrived, Circe attempted to beguile him also. To her astonishment, Odysseus was not stripped of his outer human form to reveal an underlying beastly self. Before she had recovered from this shock, Odysseus showed her the mole root and threatened to impale her on his sword.

Fearful for her life and awestruck to be in the presence of a mortal who was more than her match in cunning, Circe fell back upon her sole remaining defense, the use of her sexual charms. She desired to elevate this conflict onto the plane of erotic lovemaking. The resulting penetration of Circe would then produce not her own demise 
but rather the possibility of new life, new life formed out of the comingling of natures human and divine. Circe and Odysseus retired to her private chambers and became amorously entwined. Still untrusting of this witch, Odysseus left his unsheathed sword directly at his side while they made love. Afterwards, Circe reversed the spell she had cast on Odysseus's men, clothing them once again in their human forms.

There are several interesting correspondences worthy of note. Circe's island was surrounded by alders, a particular type of tree that was sacred to the death goddess Hecate. Circle may be seen to be a particular manifestation of Hecate. Representations of alders were commonly used as funerary designs upon the Greek gravestones of this era (Graves, 1959). In other words, in setting foot upon Circe's realm, Oddysseus and his men had entered into the grave. Appropriately, after transforming Odysseus's men into swine, Circe fed them on Cronus's cornel cherries, the "blood red" food of the dead (Graves, 1959, p. 367). In one sense, Circe's island may be seen to be a disguised form of the land of the dead.

But even more interesting perhaps is the symbolic import of lovemaking between Odysseus and Circe. This intercourse between beings human and divine represents, I argue, the creation of a new level in human consciousness. In a psychospiritual evolutionary understanding of human nature, such an act of intercourse may be seen to represent the uplifting of human consciousness from the level of the purely animal to that of a hybrid state partaking of characteristics both human and divine. Jean Houston (1992) came to much the same conclusion while exploring this same idea with deep insight and in greater depth.

After many months of leisurely rest within the realm of Circe, Odysseus's men became impatient and convinced the impassioned Odysseus that it was time to continue their homeward quest. Circe informed Odysseus that to return to the land of the living, he and his men must first sail all the way to Hades, the land of the dead. There they must consult with Teiresias, the blind prophet of Thebes. Only he could provide them with the instructions that would enable them to find their way back safely to Ithaka.

\section{Hades, Land of the Dead}

Sailing onward to the very edge of the natural world, Odysseus and his crew passed beyond the island of the god Hyperion, located 
where the sun descends each night into the great outer stream. Finally, they reached the shores of Hades. Positioned beyond the island of the sun god, the land of Hades was always dark and misty. It was never illuminated by the light of day or warmed by the rays of the sun. Disembarking from their ship, Odysseus and his men sought out the cave-like entrance leading down into the House of Hades. Once arrived, they made the obligatory animal sacrifices to the gods for protection and began the frightful task of summoning the dead.

Shortly thereafter, the hordes of the dead began to rise up out of this cave. First to come was the phantom of Odysseus's own mother, the grief-stricken Antikleia. He tried to embrace her but his arms went right through her ghostly form. She expressed her sorrow at having died without ever seeing her beloved son alive again after his departure for Troy. She spoke of the desperate circumstances on Ithaka from which she had departed in death, as the royal estate of Odysseus had gone into disrepair. Odysseus also encountered other phantoms of his past, like the Greek hero Achilles, who died on the battlefield in front of Troy, and King Agamemnon, conqueror of Troy, treacherously murdered upon his triumphant return home by his faithless, vengeful wife Klytaimnestra. But it was to consult with Teiresias especially that Odysseus and his companions had braved the passage to Hades. In the words of Odysseus:

Now came the soul of Teiresias the Theban, holding a staff of gold, and he knew who I was, and he spoke to me: "Son of Laertes and seed of Zeus, resourceful Odysseus, how is it then, unhappy man, you have left the sunlight and come here, to look on dead men and this place without pleasure? (Book XI, lines 90-94)

Teiresias continued:

"Glorious Odysseus, what you are after is sweet homecoming, but the god [Poseidon] will make it hard for you. I think you will not escape the Shaker of the Earth, who holds a grudge against you in his heart, and because you blinded his dear son hates you. But even so and still you might come back, after much suffering, if you can contain your own desire, and contain your companions." (Book XI, lines 100-105)

Teiresias then told Odysseus and his men where they must go and how they must comport themselves in order that at least some of them would return safely to Ithaka. Teiresias also prophesied that if Odysseus did successfully return to Ithaka, a long and peaceful life awaited him. Teiresias proclaimed that 
"Death will come to you from the sea, in some altogether unwarlike way, and it will end you in the ebbing time of a sleek old age. Your people about you will be prosperous. All this is true that I tell you." (Book XI, lines 134-137)

These scenes of contact with phantoms of the dead at Hades contain the most obvious examples of mythopoeic imagery compatible with the present interpretation. Modern near-death experiencers frequently report that they have been turned back at the threshold of the spirit world by the souls of the dead. Odysseus also conversed with the dead at the threshold to the spirit world, and even attempted to embrace the phantom of his deceased mother. And just as Odysseus's attempted embrace passed right through his mother's phantom form, so do we find NDErs recounting similar experiences. They report that while in the out-of-body state their "spiritual bodies" have passed right through the bodies of living doctors and nurses engaged in resuscitation efforts (Moody, 1975). There is, however, at least one striking difference between Odysseus's experience and those of modern NDErs.

In modern accounts of ecstatic journeys, the land of the dead is usually depicted as a heavenly realm where the deceased apparently reside in a condition of unsurpassed calm and serene bliss. In the Odyssey, on the other hand, the land of the dead is depicted as a shadowy realm filled with lifeless, mournful shades, shades who are only vestiges of their former living selves, vestiges that long to return to the life they once knew. Had Odysseus sailed instead to the Elysian Fields, located elsewhere at the "limits of the earth" (Book IV, lines 562-564), we would have a much better fit with the majority of modern accounts. In the world of Homer, the Elysian Fields served as the final home for those few mortals whom the gods had selected for a happy and fulfilling immortal life.

However, in a small number of contemporary cases, a realm closely resembling Hades is reported. The books of the ecstatic experience scholar Robert Crookall $(1961,1965)$ refer to a shadowy realm where souls of the dead are said to reside in a state of semiconsciousness. This realm, in Crookall's model of the afterlife, is said to be positioned between our own world and the realm of the supernatural light. Crookall even referred to this proposed dark grayish afterlife region as Hades. In his second book on NDEs, Moody (1977) referred, based upon the NDE observations of some of his subjects, to a realm of bewildered spirits. This proposed realm appears to possess many of the properties of Hades. And the ecstatic voyager Monroe (1971, 
1985) has reportedly visited any number of possible afterlife planes that would appear to correspond to the ancient Greek conception of Hades.

Returning to Odysseus's visit to Hades, we note that in the meeting with Teiresias there is yet another interesting correlation between the Odyssey and NDE-related ecstatic journeys. In a large number of NDE accounts there is described a panoramic vision of life that occasionally includes not only images of the past but also images that appear to depict events in the future of the experiencer's life (Greene and Krippner, 1990; Ring, 1984). And this life panorama is sometimes reportedly supervised by a higher spiritual intelligence. Although Odysseus himself did not envision his future, he did hear his future accurately foretold by a supernatural being, the blind prophet of Thebes. And while he did not see the past of his life in panoramic vision, he did sequentially encounter a number of significant phantoms from his past, beginning with the ghostly remnant of the one who gave him life.

\section{Song of the Sirens}

After this meeting was concluded, Odysseus and his men disembarked from Hades. They briefly stopped at Circe's island again. She warned them of the dangers that awaited them as they passed by the island of the Sirens and of two other dangerous monsters they must confront on their way home, Skylla and Charybdis. While the appearance of the Sirens was not described in the Odyssey, in postHomeric Greek urns these grotesque creatures were depicted as possessing the heads and breasts of human females and the feathered wings, claws, and bodily frames of giant birds. Thanks to the warnings of Circe, Odysseus and his men were prepared as they voyaged close to the Sirens' island. The Sirens, perched upon the shoreline, sang a song whose theme was the claim to "know all things." The promise of absolute knowledge contained in this song was irresistible to all mortal beings who would ply these supernatural seas. Whosoever heard this song became drawn irresistibly toward the Sirens. Sailors whose ships were thereby lured into the shoreline became dashed to pieces, along with their ships, upon the shoals of this supernatural land. Then came the time of feasting as the Sirens consumed their victims. 
Only Odysseus among men was crafty enough to hear the Sirens' song without paying this ultimate price. He thereby acquired the supernatural knowledge contained in this song without forfeiting his life in exchange. Once again heeding the advice of Circe, Odysseus instructed his men to bind him tightly to the mast of the ship and then stuff their ears full of wax. He cautioned his men to ignore any irrational commands that he might issue while he was mesmerized by the Sirens' song.

Finally the ship entered the range of the Sirens and they commenced their deadly serenade. As Odysseus listened to this supernatural song his sensibilities were overwhelmed and his mind unraveled. Picking through his open memories, the Sirens mimicked the voice of his beloved wife, Penelope, whom he had longed to embrace ever since disembarking from Ithaka years before on the campaign against Troy. Using her voice they beseeched him to come ever close to the shoreline. But the power of the Sirens extended even beyond this ability to penetrate the minds of mortal men. They informed Odysseus of the oppressive atmosphere surrounding his house and of the state of siege to which his wife was subject at the hands of the suitors vying against one another to marry her. Only the binding rope and the previous orders to his men saved Odysseus and his comrades from succumbing to this deadly song's irresistible attraction.

In attempting to comprehend the possible meanings of the Sirens' song, we have, I believe, come upon one of the most potent examples of mythopoeic imagery present not only in this epic but also in the whole range of mythic/epic literature. Three possible threads of meaning we shall now explore. The first involves the promise of supernatural knowledge, the second the intimation of cosmic sexual passion in the call of these female monsters, and the third, the desire to forsake life to consummate this promised union.

Ecstatic states of consciousness sometimes develop into mystical experiences. Those recounting mystical experiences sometimes report sensations of having come into contact with all knowledge or of having utterly transcended space and time. As such sentiments pertain to sexual passion, we make note of the commonly reported energistic sensations associated with ecstatic and mystical experiences. Sometimes during the onset of ecstasy and then continuing throughout the whole of this condition the conscious self is bathed with a rapturous flame likened to sexual orgasm. These sensations, however, rather than being confined to the sexual center of the physical body, 
appear to swirl throughout the whole of the spiritual body housing consciousness during ecstasy. Sexual orgasm, to be more exact, is sometimes reported to be like a shadow of these "higher" supernatural sensations (Laski, 1961).

The Sirens' song may be seen to represent that facet of ecstasy that brings on these cosmic sexual feelings. These hideously strange female creatures appealing to sailors of the opposite gender may, in addition, be seen to symbolize the power of supernatural sensory experiences to overwhelm the sensitivity levels of "ordinary mortals." In making this same point, Houston (1992) noted that the Sirens'

knowledge is clearly more than the ordinary human mind can contain, for theirs is a burning intelligence that will singe the mind away. Indeed, the Greek word seirios (siren) means "burning." (pp. 202-203)

Ecstatic otherworld voyagers who become overstimulated by this cosmic knowledge, we may speculate, lose consciousness of their ecstatic condition and "die" to the supernatural.

When ecstatic voyagers are unable to assimilate such supernatural stimuli properly, we may speculate, they descend into ordinary dream states or return to the "dream state" that is, according to some mystical teachings, identified with waking-level, body-based reality. Monroe (1971) speculated similarly, when discussing the powerful sexual vibrations whose sensations he must mediate in order to "launch" himself successfully into an out-of-body condition. But as the Sirens relate to NDEs, there is an even more obvious and compelling link.

Frequently during the midst of ecstasy entered during potentially life-threatening circumstances, the experiencer does not wish to return focus to the physical body, even if this means forgoing any effort to rescue this bodily aspect of the self from physical death. Commonly NDErs have reportedly struggled against efforts by other living persons to revive their physical bodies. Such NDErs, caught up in the thrill of ecstasy, would rather die than give up the ecstatic condition they are at that particular moment enraptured within. Once revived, however, their rational minds return and they come to realize that they were in the grip of a powerful cosmic force not apparently of this world. Elsewhere I have documented the commonality of this effect, in the only study designed specially to examine the notion of a death instinct in light of NDEs (Greene, 1982).

The following example of this patterned response is from a woman recounting an experience in which she almost died. She found herself 
freezing to death at night, in subzero conditions, after her car had become stalled in a snowbank located in a remote area. She momentarily left her car and then realized there was nowhere she could go. She returned to the car that she believed served as her tomb. She remarked that:

I was overcome by excruciating pain as the cold penetrated the depths of my body. The pain shut off all thought but soon gave way to a warm glow, which softly enveloped me. The pain was replaced by an indescribable comfort and warmth of my innermost being. Then I heard magnificent music, not of this world but from unseen stars, creating a harmony of such rapturous beauty as to lift me to a transcendence of my being.

The music is still audible in my mind, even after forty-seven years, it was of such beauty and harmony. At the same time I saw a soft glow of light-how shall I locate it-on the horizon. For a moment I was one with the Universe. Time, space, and myself were one and the same. I experienced ecstasy and I saw the unity and beauty of the Universe.

When I awoke in a hospital I struggled against those who were working to save me. I did not want to come back. However, my body soon became filled with painful "pins and needles" and I again found myself fighting for life. (Noyes and Kletti, 1976, pp. 105-106)

This superb example of what we may call the Sirens' effect upon NDErs not only illustrates the powerful grip that NDE-related ecstasy exerts upon life-threatened individuals. The effect is, even more spectacularly, directly associated with otherworldly music or with $N A D$, as this music was termed by Scott Rogo $(1970,1972)$ in his two-volume study of transcendental music. Yet another NDEr directly associated this urge to give up on life on the edge of death with the powerful pull of the Sirens. He stated that

I had wanted death to come... However, in spite of these thoughts my own last-minute efforts rescued me. In retrospect I marvel at my attraction to death. It was as though I had been lured toward my own destruction much as Odysseus was tempted by the Sirens. (Noyes and Kletti, 1976, p. 105)

\section{Final Adventures and Return to Ithaka}

Next Odysseus's ship passed by the narrow straits bounded by two other supernatural monsters, Skylla, a six-headed monster possessing enormous fangs, and Charybdis, a whirlpool monster who sucked 
sailors down to their deaths at the bottom of the sea. To save at least a portion of his crew, Odysseus avoided Charybdis and steered his ship toward Skylla. He was prepared to make this choice in deference to the words of Circe. This monster grabbed six men and swallowed them alive and kicking while the rest of the ship's occupants passed through the strait safely.

Following this calamity Odysseus and his remaining crew came once again to the island of the sun god Hyperion. They landed there for water and then found themselves stranded on this island for a month because of a lull in the wind. As they became ever more famished, Odysseus's crew decided it was better to risk the wrath of the gods than to die of starvation. They feasted upon the forbidden sacred livestock of Hyperion. Odysseus, away from his men on another part of the island during this feast, escaped the ensuing divine curse that doomed his men. Later, after their ship had caught a wind to escape this island, Odysseus's whole remaining crew drowned in a stormy sea as their ship was split apart by a thunderbolt from Zeus. Thus did the "Lord of the Thunderbolt," Zeus, avenge this eating of $\mathrm{Hy}$ perion's sacred cattle.

Only Odysseus, who had not eaten these cattle and had consequently escaped the curse, now remained, clutching onto a wooden beam from the ship. Days later, he washed ashore on the island of the nymph Kalypso. The name of this island, interestingly, was Ogygia, meaning "navel of the sea." And from Ogygia there extended an opening leading down into the underworld. Kalypso's cavern was surrounded by alders. Alders, we have already noted, were sacred to the death goddess Hecate. Kalypso may, in fact, be seen as another manifestation of Hecate (Lockhart, 1983). Thus even now Odysseus had yet to escape the pull of Hades.

After seven years of "amorous captivity" in the arms of Kalypso, finally Odysseus was able to build a raft and return to the realm of mortal men. He first disembarked upon the shores of the Phaiakians and maintained a disguise until he felt he was safe in their presence. He was treated as a worthy guest by Alkinoös, king of this land, and told of his wanderings in the exotic lands he had visited. Eventually, the Phaiakians presented him with numerous gifts and provided him with safe conduct back to his homeland of Ithaka. Upon arriving home, he once again disguised himself, this time as a beggar of alms. In this way he penetrated his own palace, where he was able to surmise just how stifling was the pressure of the suitors on his wife. When the proper moment arrived he revealed his true identity and 
with the help of his son Telemachos, quickly dispatched each and every suitor, spilling their blood down into Hades. After twenty years of longing, finally he found himself reunited in the arms of his faithful, loving wife Penelope. As foretold by Teiresias, Odysseus lived out his life prosperously. Thus ended the first epic journey into the supernatural recorded in Western literature.

\section{The Homeric "Hymn to Demeter" and the "Wine Dark Sea"}

In associating the imagery of water passage with the $\mathrm{OBE}$, we have, I believe, drawn attention to the powerful experiential as well as symbolic role that water imagery plays in this epic. Yet we have not, in my view, exhausted the possible import of water imagery present within Homer's Odyssey. Additional significance may be found in contemplating the possible meaning of the stock epithet "wine dark sea" uttered throughout the Odyssey.

This particular correlation begins to become more evident when we realize that mystery traditions in ancient Greece had, for thousands of years, invoked the used of wine to induce ecstasy. But no ordinary wine was used, as we recognize the constituent properties of alcohol today. Gordon Wasson, Ruck, and Albert Hoffman have established, in their remarkable collaborative work The Road to Eleusis (1978), that the wine consumed during these religious rites contained, in all likelihood, powerful hallucinogens. In the most famous of these mystery traditions, the Eleusinian mysteries, these hallucinogens, Wasson, Ruck, and Hoffman speculated, were produced from the ergot collected off wheat and from other naturally occurring substances also possessing psychedelic properties.

More recently, Terrence McKenna (1992) has argued persuasively for the psilocybin mushroom as the principle hallucinogen used at Eleusis. In either view, the act of sailing out into the "wine dark sea" may be equated symbolically with the consumption of a mindaltering liquid known to induce ecstatic journeys (Grof, 1985; Masters and Houston, 1967; McKenna, 1992). Thus by drinking this powerful hallucinogenic brew the initiate might come to be propelled through the sea of a higher supernatural realm and partake of the knowledge thereby gleaned.

Remarkable, in light of this speculation, is the fact that the "Homeric Hymn to Demeter" (Ruck, 1978) (the Homeric hymns were ac- 
tually composed centuries after Homer's great epic), the primary instructional text used in the Elysinian mystery rites, is modeled in part upon a particular passage from the Odyssey. This religious text is based upon the masked appearance of Odysseus at the court of the Phaiakians during the last phase of his supernatural journey.

In this "Hymn," Demeter, goddess of vegetation or life, also entered a royal household in disguise, a household located near an entrance leading down into the House of Hades at the town of Eleusis. Just as Odysseus eventually revealed his true identity to the Phaiakians, so also do we find that Demeter, disguised as a nursemaid, eventually revealed to the members of this household her true identity as goddess of life. Just as Demeter sacrificed the royal child she had nursed during her disguise, in effect offering him to Hades in exchange for her daughter Persephone, so also do we find that all of Odysseus's men eventually died, in order that he might return to the land of the living.

\section{Odysseus as a Shamanic Initiate}

Another correlate linking the ecstatic journey to the voyage of Odysseus we have yet to consider involves the reported spiritual transformations in the lives of persons surviving NDEs (Ring, 1984). In the case of Odysseus, there was also a profound transformation in character, the direct result of the supernatural obstacles he had endured and overcome to reach his home shore. The whole story of Homer's Odyssey may be read as a rite of passage to a higher, more evolved state of being (S. Harris, personal communication, December 2,1987 ). This rite of passage was very similar to the rituals practiced by shamans (Eliade, 1962). Like the shaman, Odysseus had to endure extraordinary obstacles in order to be spiritually transformed.

Like the shaman, whose higher state of being is formed out of the reconstitution of his dismembered body, Odysseus had had to unify his discordant lower instincts and unruly human appetites into a single higher purpose, the quest to return to the land of the living. Within the context of this interpretation, the near-drownings he had survived are seen to be a form of spiritual baptism. That only he among all of his companions possessed the perseverance, stamina, and intelligence required to overcome all of these obstacles demonstrated that only he could partake in the transformation of being that was required in order to return from the supernatural to the 
natural world. And only the shaman, within the context of shamanism, may journey safely into the supernatural and return to the world of nature.

In his historical and literary study of otherworld journeys, Couliano (1991) also identified Odysseus as a shaman, or rather as an "apprentice shaman." Couliano noted that the rituals Odysseus followed while engaged in "soul raising" at the mouth of Hades derived from the native shamanic tradition of ancient Greece. Couliano also identified the practitioners of ancient Greek shamanism as under the aegis of "Apollo of Hyperborea." Such an alignment may be seen to associate these practitioners with the Indo-European invaders who entered Greece from the north around 2000 BC. As Couliano observed,

The old European goddess culture [and its matriarchal society] was brutally replaced by the patriarchal Indo-European culture of seminomadic herdsmen, whose values were destruction, war, and violence based on a male code of behavior... Open cities were replaced by walled ones, native goddesses became consorts, were transformed into males, or were recast as monsters. (1991, p. 116)

Within such a historical perspective, those elements in Homer's Odyssey possessing a historical basis may be read as literary reflections of this Indo-European invasion. For example, the events surrounding Odysseus's subjugation of Circe may be seen to represent conquest by Indo-European invaders of an older matriarchal society.

\section{The Question of Symbolic Imagery}

From the beginning, I have argued that Homer's Odyssey is imbued with profound symbolic import. The launching of the Greek ships into the mysterious western sea I have equated with the ingestion of a hallucinogenic brew intended to induce ecstasy; the "Song of the Sirens" I have equated with the powerful orgasmic energies sometimes associated with ecstasy and also with the possible dangers of being overwhelmed by these energies. Finally, the narrow straits, caves, and whirpools I have equated with the passage by ecstatic voyagers through dark and swirling tunnels and other fluidic currents. The use of symbolic imagery points toward an intelligence behind the symbolism, an intelligence that has intentionally employed this imagery for some reason. But who or what was this intelligence and for what reason has it employed this symbolism? 
The most obvious initial candidate would be Homer himself. But who was Homer? To this question we will never have a satisfactory answer. Homer, some scholars believe, may well have been an actual man, a blind bard in the tradition of traveling bards living in the vicinity of the Aegean Sea around the year $850 \mathrm{BC}$. He may also have been a mythic personage himself, a sort of composite figure of numerous traveling bards who then lived in the proximity of Greece. In granting either view, the works attributed to Homer acquired their final written form over a number of centuries and combined the orally transmitted epics and legends of various peoples and traditions into two unified literary texts, the Iliad and the Odyssey.

Even accepting the historical existence of Homer, there is little doubt that his primary achievement was as a collector and synthesizer of diverse legends rather than as an entirely original thinker. Homer's function as a collector of legends leads me to wonder how credible the proposition is that he could have intentionally incorporated all of the ecstatic experience-related imagery into the Odyssey that I have identified in this paper. As noted, on one level, the events depict not a wandering around in some afterlife state but rather a wandering around the Mediterranean Sea during the chaotic period when Indo-European invaders were subduing older matriarchal societies.

But there is another reason to dismiss the possibility that Homer intentionally employed imagery symbolic of the ecstatic journey. Some contemporary scholars of classical repute (Jaynes, 1976; Lattimore, 1965) do not believe that the capacity to think and articulate ideas symbolically had yet developed at the time Homer lived. Only during the classical period, beginning some 150 years after Homer's death, so goes this argument, did Greek intellectuals begin to display an aptitude for the symbolic use of language. Granting the viability of such a view, who or what then was the intelligence employing symbolism in the Odyssey? While there is a tendency in our modern age of scientific rationalization to dismiss automatically as unthinkable certain explanations for literary inspiration, the most credible explanation, I believe, may be found among the ancient Greeks themselves.

The power of symbolic mastery over language in Homer's Odyssey came, I argue, from a supernatural source, from a "divine muse" existing above the human condition and outside of space and time. In Plato's "Apology," Socrates stated that 
not by wisdom do poets write poetry, but by a sort of genius and inspiration; they are like diviners or soothsayers who also say many fine things, but do not understand the meaning of them. (Plato, 1924, p. 108)

Whether we think in term of a supernatural intelligence completely distinct from human existence or rather of a higher supernatural level of human consciousness that has yet to become integrated into the natural human intellect is irrelevant to the present discussion. In either case, I believe, we have a working hypothesis potentially capable of illuminating the reasons why imagery profoundly symbolic of ecstatic journeys breathes life into Homer's Odyssey.

To this higher intelligence, existing in a more spacious present moment-that subsumes much larger portions of space and time together-simultaneously accessing information from different historical periods might be no more difficult than for us to glance back and forth at the objects on our living room table and the painting on the wall behind. Like the Jungian archetypes adapted into an explanatory model for NDEs by Michael Grosso (1985), the mythopoeic imagery of which I speak may be said to be charged with a surplus of meaning. This surplus comes from the ability of this supernatural intelligence to draw upon patterns in the cosmos lying outside sentiently perceived space and time.

Various examples of imagery in the Odyssey possess more than a one-to-one physical world correspondence because, I submit, they conform to a wider cosmic pattern whose organization transcends mundane human conceptions of space and time. In other words, I am arguing that the meanings present in Homer's Odyssey are multileveled, that this work may be read both as a memory of actual wanderings through the Mediterranean Sea by ancient sailors and as an experiential and symbolic journey into the afterlife. The water imagery in Homer's Odyssey, for instance, may be seen to possess at least five different levels of meaning relevant to the notions of ecstasy. This is as opposed to the one-to-one connective relationship between things we are conditioned to perceive from our sensory experiences in the physical world.

The first level of meaning involves the use of water imagery to signify the threat of drowning as a potential catalyst of NDE-related ecstasy. The second involves the launching of the Greek ships out into the mysterious western sea that may be equated symbolically with the OBE. The third involves the use of water to symbolize liquid 
forms of hallucinogens as potential triggers for ecstatic journeys. A fourth involves the use of water imagery to represent an actual experiential correlate of passage between physical, psychical, and mystical levels of the cosmos, as J. M. H. Whiteman (1978) has observed. And yet a fifth level involves the use of water imagery as symbolic of spiritual baptism or initiation, as I have observed in looking upon Odysseus as a shamanic initiate.

The Song of the Sirens offers us yet another example of mythopoeic imagery suggesting the existence of complex, multifaceted cosmic patterns underlying this epic, patterns shaped, I argue, by an intelligence existing outside of space and time. Cosmic sex and physical/psychological death and associated pleasures and pains, as well as degrees of supernatural stimuli too psychospiritually awesome to be humanly endured, are all somehow intimated in the Song of the Sirens. The supernatural intelligence infusing life into Homer's imagery, I believe, conveys to us insights whose truth value transcends human understanding. In other words, the infinite infused via poetic inspiration into the finite cannot help but flood the islands of physical world sensory knowledge, thereby engulfing linear systems of thought and overwhelming the single cause-and-effect relationships to which "ordinary mortals" are conditioned to respond.

And this is why, perhaps, such intellectually perplexing waters separate the natural level of the cosmos from the supernatural, and human from divine degrees of insight and wisdom. The numbing effect that sensory overload has been demonstrated to have upon the human mind (Oswald, 1965) may perhaps intimate to us something of our relationship to the supernatural, whose numinosity may be too brilliant for us to perceive directly while remaining conscious and alive in this world. Perhaps as successive generations of human wonderers continue to ponder the meanings infused within such works as Homer's Odyssey a stretching effect reaches across the human species as a whole. Stimuli that had previously been too intense to be received and articulated humanly are finally able to filter through to a later generation of human wonderers, wonderers who are better able to give utterance to that which was previously ineffable. In other words, as a consequence of psychospiritual evolution, it may be that ever increasing numbers of living human beings are able to remember and articulate personal experiences of ecstatic journeys into supernatural worlds. 


\section{The Supernatural in Homer's World and Today}

Perhaps the greatest barrier to the acceptance of my thesis comes from the greatly varying cosmic conceptions that underlie our modern "scientific" cosmology and the cosmic conceptions of the Mycenaean Age. How can we seriously attribute any reality to the epic events of Homer's Odyssey when these events are set inside the context of a primitive and objectively false worldview? This is a worldview wherein one need only keep sailing west in order to pass from the natural universe into the supernatural. From our modern cosmic perspective the supernatural, if it exists at all, lies not beyond the "edge" of the Earth, for there is no edge.

Rather the supernatural must exist outside of or above the very confines of the natural universe. The supernatural, presuming its existence, must be located beyond space and time- space and time, that is, as we now recognize these baseline parameters of human existence. The realm of the supernatural may be located, perhaps, in some superior dimension, perhaps in a world possessing four spatial dimensions. This is in much the same way as we may conceive our own world of three dimensions to be superior to a world of two dimensions that, in turn, is superior to a world possessing one dimension.

In other words, passage into the supernatural universe would involve a process where waking human consciousness ascends, in some transformed state of being, out of our familiar world of three dimensions into the more spatially comprehensive world of four dimensions. During ecstasy, ordinary sensory/perceptual awareness has, in this view, temporarily awakened from the dream state of three-dimensional reality. Elsewhere I have proposed such an explanation for ecstatic experiences (Greene, 1981, 1984a, 1984b; Greene and Krippner, 1990). The higher space argument may be seen to become even more provocative when we once again reconsider, within the context of that argument, the commonly reported sensations of floating associated with the initial stages of ecstasy.

In speaking of the physical world we commonly say that we have access to movement in three dimensions. Yet in a certain sense this is only partially true. While we may easily traverse an entire continent, given the time and circumstance, by moving across two of the three dimensions to which we have access, our ability to move in the third direction is immeasurably more limited. Few of us can jump unaided more than two or three feet into the air. Thus our capacity to move is, in one sense at least, far more two- than three-dimen- 
sional. If in this postulated higher-dimensional world there is a hyperphysical force that corresponds in some sense or other to gravity in our present world, then we might expect the following condition to hold true.

Upon initial penetrations into this four-dimensional world our capacity to move-that is, to float-rather effortlessly would be confined to three dimensions, with some extra effort required to exercise movement along the fourth spatial axis. This reasoning might help to explain why sensations of floating and effortless movement in three dimensions, including passages through three-dimensional walls and other physical obstructions, frequently seems to precede the more profound alterations in consciousness associated with ecstatic experiences. Here I am referring to episodes of "time traveling" and penetrations into "other realms." I am also referring to expansions into mystical states of consciousness during which experiencers appear to become engulfed within God and/or to have entered eternity.

In conclusion, I will leave readers with one additional thought to ponder. This involves a similarity that I have often contemplated between modern cosmological ideas and those of the Mycenaean Age. To appreciate this notion we must resort once again to higher-space reasoning. We can easily visualize the drawing of a circle on a piece of paper. It takes little additional thought to imagine that this circle represents a one-dimensional world embedded inside a "higher" twodimensional plane space. Similarly, we can easily visualize a two-dimensional surface curved completely in upon itself as it extends through the third dimension. We call this geometrical object a sphere.

It takes little additional thought to imagine that this sphere represents a two-dimensional world that is imbedded inside a higher three-dimensional space. Here I do not wish to confuse any possible inhabitants of such a "curved" two-dimensional world with three-dimensional beings, such as ourselves, who inhabit the outer edge of the surface of the oblate spheroid we call the planet Earth. I am, rather, referring to two-dimensional beings imbedded "inside" this curved surface. For them there would be no "up" or "down" but only passage "across" the plane inside of which they live. Now our exercise begins to become "visually" foggy. Most of us will have to leave behind our capacity for visualization, although we may still take along with us our capacity for abstract reasoning. It is logically possible and geometrically correct to conceptualize that our own world of three dimensions curves back in upon itself by extending through a higher space. 
However difficult it might be for us to visualize such a condition, contemporary cosmologists seriously contemplate this notion on a daily basis. Our own three-dimensional world, in ways that we may find extremely difficult if not impossible to visualize, may actually be surrounded by a space extended in four dimensions. One view of Albert Einstein's theory of general relativity is that our own threedimensional space does actually curve back in upon itself by extending through such a fourth dimension. For the adventurous thinker interested in further exploring these ideas, the books of Rudolph Rucker (1984), Paul Davies (1980), and Edward Harrison (1985) are excellent introductions.

Returning to the world of Homer, we find that a similar geometrical relationship orders the Mycenaean cosmos. This disk-shaped universe that is cosmologically speaking two-dimensional is also surrounded on the outside, above, and below by a supernatural realm. Lacking entirely in any conception of higher mathematics and possessing only a poorly developed faculty for abstract reasoning, the ancient Greeks of this far-off age, I believe, came as close as they possibly could to envisioning the true relationship between nature and supernature. Their greatest mistake, as the mythologist Joseph Campbell (1951) might have said, was in confusing metaphorical with literal levels of understanding.

\section{References}

Audette, J. (1982). Historical perspectives on near-death episodes. In C. R. Lundahl (Ed.), A collection of near-death research readings (pp. 21-43). Chicago, IL: NelsonHall.

Black, D. (1975). Ekstasy. New York, NY: Bobbs-Merrill.

Campbell, J. (1949). The hero with a thousand faces. Princeton, NJ: Princeton University Press.

Couliano, I. P. (1991). Out of this world: Otherworld journeys from Gilgamesh to Albert Einstein. Boston, MA: Shambhala.

Crookall, R. (1961). The study and practice of astral projection. Secaucus, NJ: Citadel Press.

Crookall, R. (1972). The case book of astral projection. Secaucus, NJ: Citadel Press.

Davies, P. (1980). Other worlds. New York, NY: Simon and Schuster.

DeQuincy, T. (1956). Confessions of an English opium eater with its sequelae, suspiria de profundis and the English mail coach. (M. Elwin, Ed.). London, England: MacDonald. (Original work published 1862)

Eliade, M. (1962). Shamanism: Archaic techniques of ecstasy. New York, NY: Pantheon.

Frazer, J. (1922). The golden bough. New York, NY: Macmillan.

Gallup, G., and Proctor, W. (1982). Adventures in immortality: A look beyond the threshold of death. New York, NY: McGraw-Hill.

Graves, R. (1959). Greek myths (Vol. 2). New York, NY: George Braziller. 
Greene, F. G. (1982). Thanatos: The death instinct. In M. C. Rose (Ed.), Academy of Religion and Psychical Research 1982 Annual Conference Proceedings (pp. 110-121). Bloomfield, CT: Academy of Religion and Psychical Research.

Greene, F. G. (1983). The out-of-body experience, extrasomatic or intrasomatic phenomenon? A non-Euclidean/higher space approach. Journal of Religion and Psychical Research, 6, 159-180.

Greene, F. G., and Krippner, S. (1990). Panoramic vision: Hallucination or bridge into the beyond? In G. Doore (Ed.), What survives? Contemporary explorations of life after death (pp. 61-75). Los Angeles, CA: Tarcher.

Grof, S. (1985). Beyond the brain: Birth, death, and transcendence in psychotherapy. Albany, NY: State University of New York Press.

Grosso, M. (1985). The final choice: Playing the survival game. Walpole, NH: Stillpoint Press.

Harrison, E. (1984). Masks of the universe. New York, NY: Macmillan.

Homer. (1967). The Odyssey of Homer (Trans. by R. Lattimore). New York, NY: Harper and Row.

Houston, J. (1992). The hero and the goddess. New York, NY: Ballantine.

Irwin, H. J. (1985). Flight of mind: A psychological study of the out-of-body experience. Metuchen, NJ: Scarecrow Press.

Jaynes, J. (1976). The origin of consciousness in the breakdown of the bicameral mind. Boston, MA: Houghton Mifflin.

Lattimore, R. (1967). Introduction. In R. Lattimore (Ed.), The Odyssey of Homer (pp. 1-24). New York, NY: Harper and Row.

Lockhart, R. (1983). Words as eggs. Dallas, TX: Spring Publications.

Masters, R., and Houston, J. (1967). Varieties of psychedelic experience. New York, NY: Holt, Reinhart and Winston.

McKenna, T. (1992). Food of the gods. New York, NY: Bantam.

Monroe, R. (1971). Journeys out of the body. Garden City, NY: Doubleday.

Monroe, R. (1985). Far journeys. Garden City, NY: Doubleday.

Moody, R. A. (1975). Life after life. Covington, GA: Mockingbird Books.

Moody, R. A. (1977). Reflections on life after life. St. Simon's Island, GA: Mockingbird Books.

Noyes, R., and Kletti, R.(1976). Depersonalization in the face of life-threatening danger: An interpretation. Omega, 7, 103-114.

Oswald, I. (1966). Sleep. New York, NY: Penguin.

Plato. (1924). The works of Plato. (B. Jowett, Trans.). New York, NY: Dial Press.

Ring, K. (1980). Life at death: A scientific investigation of the near-death experience. New York, NY: Coward, McCann and Geoghegan.

Ring, K. (1984). Heading toward omega: In searh of the meaning of the near-death experience. New York, NY: Morrow.

Rogo, D. S. (1970). NAD: A study of some unusual "other world" experiences. New York, NY: University Books.

Rogo, D. S. (1972). NAD: A psychic study of the "music of the spheres." New York, NY: University Books.

Rogo, D. S. (Ed.) (1978). Mind beyond the body. New York, NY: Penguin.

Ruck, C. (1978). Documentation: Vision at Eleusis. In R. G. Wasson, C. Ruck, and A. Hoffman (Eds.), The road to Eleusis. New York, NY: Harcourt Brace Jovanovich.

Rucker, R. (1984). The fourth dimension: Toward a geometry of higher reality. Boston, MA: Houghton Mifflin.

Staples, D. (Trans.). The Homeric hymn to Demeter. In R G. Wasson, C. Ruck, and A. Hoffman (Eds.), The road to Eleusis. New York, NY: Harcourt Brace Jovanovich. Whiteman, J. (1978). The process of separation and return in experiences fully "outof-body." In D. S. Rogo (Ed.), Mind beyond the body. New York, NY: Penguin. 